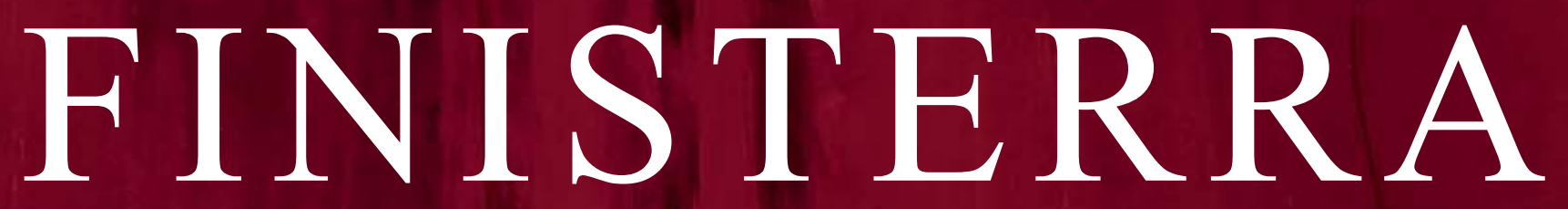

Revista Portuguesa de Geografia

Centro

de Estudos

Geográficos

Volume LII

Número 106

Dezembro 2017 


\title{
MAPPING OF LAND UNITS AND LAND CAPABILITY CLASSIFICATION IN PORTUGAL: THE CASE OF THE MUNICIPALITY OF LOURINHÃ
}

\author{
RITA LOPES ${ }^{1}$ \\ Manuel Madeira ${ }^{2}$ \\ PEDRO ARSÉNIO ${ }^{3}$
}

\begin{abstract}
Land units can be an advantageous tool in landscape planning, in land suitability and land capability classification. It is vital to deepen the knowledge on their delimitation procedures, particularly in areas where available data is scarce and presents a certain complexity. The municipality of Lourinhã, based on sedimentary rocks, was chosen as a case study. Land units were mapped using lithological units (1:50 000), landform types and soil unit (1:25 000) information. Several inadequacies were observed both in the soil and soil capability maps ${ }^{i}$. There was evidence of a strong information deficiency on the basic characteristics of soil units and the presence of rock outcrops was not revealed in such maps. From the lithological units and landforms, 33 basic physiographic units were delimited, and their association with soil units resulted in an equal number of land units, afterwards generalized. The delimited land units have proven to be suitable for a land capability classification at the municipality scale, revealing great potential to identify the nature and severity of the major land (and soil) degradation risks. Also, they prove to be useful for improvement of the soil capability classification and to standardize the definition of the National Agricultural Reserve by using identical delimitation criteria.
\end{abstract}

Keywords: Landforms; soils; GIS; land classification; landscape planning.

1 Landscape Architecture Master's degree, School of Agriculture, Universidade de Lisboa, Tapada da Ajuda, 1349-017, Lisboa, Portugal. E-mail: pereiralopesrita@gmail.com

2 Full Professor and Researcher at the Forest Research Centre, School of Agriculture, Universidade de Lisboa, Tapada da Ajuda, 349-017, Lisboa, Portugal. E-mail: mavmadeira@isa.ulisboa.pt

3 Professor and Researcher at the LEAF Research Centre - Linking Landscape, Environment, Agriculture and Food, School of Agriculture, Universidade de Lisboa, Tapada da Ajuda, 349-017, Lisboa, Portugal. E-mail: arseniop@isa.ulisboa.pt 
RESUMO - A DELIMITAÇÃO DE UNIDADES DE TERRA E A CLASSIFICAÇÃO DA CAPACIDADE DA TERRA EM PORTUGAL: O CASO DO CONCELHO DE LOURINHÃ. As unidades de terrai ${ }^{\text {ii }}$ podem ser um instrumento vantajoso no ordenamento do território, na avaliação da aptidão e da capacidade da terra. É crucial aprofundar o conhecimento dos procedimentos da sua delimitação, nomeadamente em áreas onde a informação apresenta alguma complexidade. Como caso de estudo optou-se pelo concelho de Lourinhã, que assenta sob formações sedimentares. As unidades de terra foram mapeadas a partir da geologia (1:50 000), formas de relevo e solos (1:25 000). Observaram-se inadequações na carta de solos, bem como na respectiva carta de capacidade de uso do solo. Constatou-se uma forte deficiência de informação sobre as características das unidades de solos e os afloramentos rochosos não eram evidenciados em tais mapas. A partir das unidades litológicas e das formas de relevo delimitaram-se 33 unidades fisiográficas básicas, e a sua associação com as unidades de solos resultou em igual número de unidades de terra, posteriormente generalizadas. As unidades de terra delimitadas mostraram-se adequadas para a classificação da capacidade da terra à escala municipal, revelando um grande potencial para identificar a natureza e intensidade dos principais riscos de degradação da terra (e do solo). Além disso, provaram ser uma via adequada para o aperfeiçoamento da classificação da carta de capacidade de uso do solo e para a padronização da definição da Reserva Agrícola Nacional utilizando critérios de delimitação idênticos.

Palavras-chave: Formas de relevo; solos; SIG; classificação da terra; ordenamento do território.

RÉSUMÉ - LA CARTOGRAPHIE DES TYPES DE TERRAIN ET LA CLASSIFICATION DE LEUR CAPACITÉ PRODUCTIVE AU PORTUGAL: LE CAS DU CANTON DE LOURINHÃ. La détermination des Types de terrain, selon leurs aptitudes et leur capacité d'utilisation, peut être un instrument efficace d'organisation du territoire. Il serait fondamental d'améliorer les processus de leur délimitation, surtout dans les régions où celle-ci présente une certaine complexité. On a choisi le cas du canton de Lourinhã, en terrain sédimentaire. Les types de terrain y ont été cartographiés à partir des cartes géologiques (au 1:50 000), du relief et des sols (au 1:25 000). Des erreurs ont été détectées sur les cartes des sols et de leur capacité d'utilisation. On a constaté une forte déficience d'information sur les caractéristiques des divers types de sols et une totale absence d'information sur les affleurements rocheux. On a délimité 33 unités physiographiques de base, à partir des données lithologiques et morphologiques et, en les associant aux données pédologiques, on a obtenu un même nombre de types de terrain. Ceux-ci ont alors été classés selon leur productivité, à léchelle du canton, ce qui a beaucoup aidé à déterminer la nature et l'intensité des principaux risques de dégradation de ces terrains et des sols. C'est aussi un moyen efficace d'améliorer la carte de capacité d'utilisation des sols et de généraliser les critères de délimitation à utiliser pour la définition de la Réserve Agricole Nationale.

Mots clés: Formes de relief; sols; SIG; classification des terrains; aménagement du territoire. 


\section{INTRODUCTION}

Land units are an essential tool for several landscape planning applications as they express a "tract of land that is ecologically homogeneous at the scale level concerned" (Zonneveld, 1989, p. 68). Land units have also been used as a mapping tool and provide a basis for land suitability and land capability assessment (Zonneveld, 1989, p. 68; OEH, 2012).

Recent studies demonstrate that land units can be used as a main concept in the resolution of landscape planning issues. For instance, Blasi, Zavattero, Marignani, Smiraglia, Copiz, Rosati, and Del Vico (2008) used the land unit approach to design an ecological network of sites in the Rome Province (Lazio, Italy), in order to fulfill the main ecological needs of species, community and ecosystems. Also, Capotorti, Guida, Siervo, Smiraglia, and Blasi (2012) used land units as a tool to describe the ecological classification of land in Italy and show how these units can act as reliable frameworks to implement national conservation strategies. In addition, the land capability mapping in Tasmania was developed using land units, that is, homogeneous units in terms of climate, relief, lithology and soils (Grose, 1999)

In Portugal, the land unit concept has been only partially developed in soil surveys associated with the evaluation of land suitability. In particular, Agroconsultores and Coba (1991) in the elaboration of the Portugal Northeast soil map delimited natural regions corresponding to large landscape units combining physiographic features (that is, landform types), climate, vegetation and land use, thus creating homogenous zones approaching the land unit concept. Later, Agroconsultores and Geometral (1995) also produced the Entre-Douro and Minho soil and land suitability maps at 1:100 000 scale, delimiting large morpho-climatic units, relatively homogenous as to climate, lithology, geomorphology, topographical conditions, vegetation and land use. Meanwhile, Abreu, Pinto, \& Oliveira (2004) defined landscape units, at the national level, as areas where the landscape presents a specific pattern associated with a particular character, defined by geomorphology, lithology, soils, land use, farm dimension, human settlement pattern, climate, proximity of the sea and presence of important structures and infrastructures. Although the delimitation procedure of landscape units (Abreu et al., 2004) is not quite clear, the concept adjusts itself fairly to the land definition as expressed by FAO (2007).

Despite the scarce applications of the land unit concept in Portugal, the legislation regulating the National Agricultural Reserve (Reserva Agricola Nacional, RAN) recognizes the need for the delimitation of homogenous areas defining land units and pointing out that "the land units that present a high or moderate suitability for agriculture", are to be integrated in the RAN, after being classified "according to the classification methods of the land suitability classification recommended by the Food and Agriculture Organization (FAO)" (articles $8^{\text {th }}$ and $6^{\text {th }}$ of Decree Law $n^{\circ} 73 / 2009,31^{\text {st }}$ March, respectively). As large areas of Portugal still requires classification, such law foresees that, when it is alternatively possible to use the FAO classification, it is also possible to affiliate into RAN "the areas with soil capability classes A, B and Ch", or "alluvial or colluvial areas" or else areas where these classes are largely represented. Besides the absence of the classification rec- 
ommended by FAO $(1976,2007)$ in the most part of the country, the soil capability map shows deficiencies, namely in the littoral central region, where soil capability units were not adequately framed with the general system of the Official Soil Service (SROA, 1973; IDRHa \& SPCS, 2005). It should be emphasized that "soil capability map" and soil "capability classification" are a translation of the Portuguese terms carta de capacidade de uso do solo and classificação da capacidade de uso do solo (SROA, 1972), which approximately correspond to the land capability classification (Klingebiel \& Montgomery, 1961). Although the aim was to develop a classification based on the land capability classification (by the United States Soil Conservation Service), the soil capability classification (in Portugal) did not consider the climate and was based on less detailed soil information compared to that used in the USA (SROA, 1972).

Since the land unit concept is rarely used in Portugal and is considered in the legislation that regulates RAN areas, it is therefore crucial to implement the methodology regarding land units mapping and to evaluate whether RAN areas can be assessed, especially where the information is scarce and presents great complexity. In this context, a study was developed aiming to (i) analyze the land unit concept applicability, (ii) develop a methodology in areas where the existing data is considered insufficient, (iii) evaluate how much land units are in accordance with the existing soil capability units, and (iv) assess whether the land unit delimitation can lead to a unifying methodology for the RAN delimitation. As a case study, the municipality of Lourinhã (an area based on sedimentary rocks) was chosen, since it is used intensively for agricultural purposes.

\section{METHODOLOGY}

\section{Study area}

The study was carried out in the municipality of Lourinhã located in Portugal's West Coast, part of the Lisbon district (fig. 1). It comprises an area of about $147 \mathrm{~km}^{2}$ with a population of ca. 25000 inhabitants. The majority of the territory is used for temporary crops (fig. 1); thence the landscape is profoundly influenced by agricultural activity (fig. 1), especially horticulture. The area exhibits mild temperatures, high relative humidity, and low frost risk in winter. According to the climate based on the closest weather stations and/or pluviometric stations (Reis \& Gonçalves, 1981), for the period of 1951/1981, the mean annual precipitation (MAP) in Lourinhã varied from 600 to $700 \mathrm{~mm}$, since it was $567 \mathrm{~mm}$ in Cabo Carvoeiro, $608 \mathrm{~mm}$ in Caldas da Rainha and $780 \mathrm{~mm}$ in Torres Vedras. The daily temperature range is relatively narrow, given the small difference between the mean maximum and the mean minimum temperature, either in the warmest month or in the coldest month. In Cabo Carvoeiro, the closest station to the ocean, the range is $4.5^{\circ} \mathrm{C}$ in the warmest and $5.3^{\circ} \mathrm{C}$ in the coldest month; in Caldas da Rainha the range is more pronounced: $8.5^{\circ} \mathrm{C}$ in the warmest month and $7.7^{\circ} \mathrm{C}$ in the coldest month, probably because of its greater distance from the ocean. The monthly mean relative humidity of the air is high and above $77 \%$ in Caldas da Rainha, and $81 \%$ in Cabo Carvoeiro. 


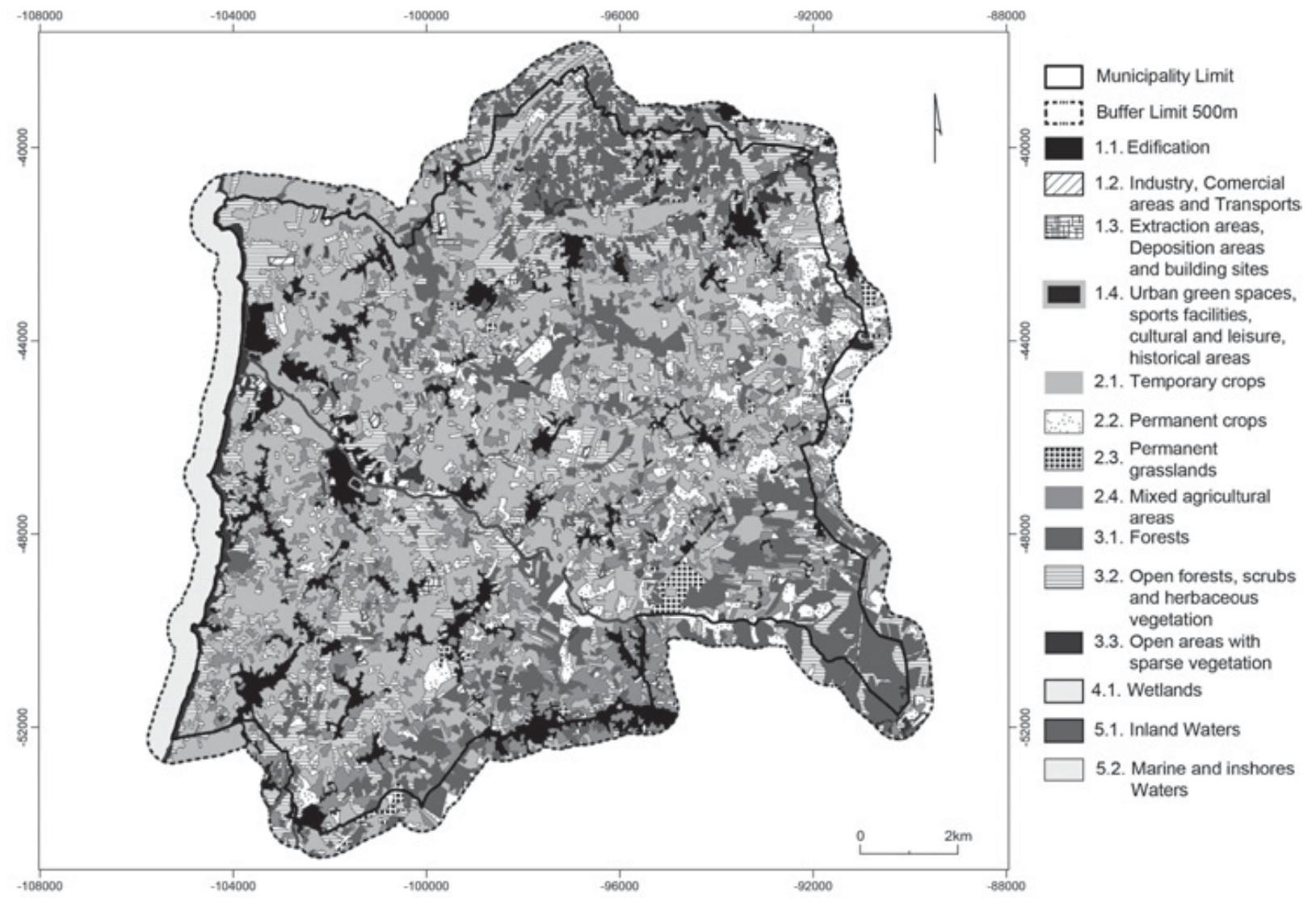

Fig. 1 - Location and limits of the Municipality of Lourinhã and Occupation and Soil Use Map COS 2007 (Direcção-Geral do Território, 2007).

Fig. 1 - Localização e limites do concelho de Lourinhã e Carta de Ocupação e Uso do Solo COS 2007 (Direcção-Geral do Território, 2007).

\section{Reorganization of data and land unit delimitation}

The procedure for land unit delimitation (see flowchart of fig. 2) was adjusted to the available data for the study area, respecting the fundamental concepts introduced by Zonneveld (1995). After collecting basic available data, field observations were carried out. Following the field observations, it was possible to aggregate and dimension the geological formations and landform types. Geological formations were aggregated into lithological units, the alluvial and colluvial areas being taken from the soil map of Portugal, since its scale was more appropriate. Landform analysis was performed according to the Hammond (1954, 1964a, 1964b) methodology and aggregated into landform types. Soil information from the Portugal soil map (using the Portugal Soil Classification, PSC) (SROA, 1973; IHDRA, 1999) was inferred to the World Reference Base for Soil Resources (WRB, 2006) resulting in eight soil-mapping units. Lithological units and landform types were intersected resulting in basic physiographic units; to each of these units, information regarding soil units, as a qualitative attribute, and rock outcrops were added. The land cover map COS 2007 Level 2 (1:25 000) (Direcção-Geral do Território, 2007) and the soil capability map (1:25 000) (DGADR) were also used to support the analysis of land units. Therefore, the obtained land units were afterwards grouped into generalized land units. 


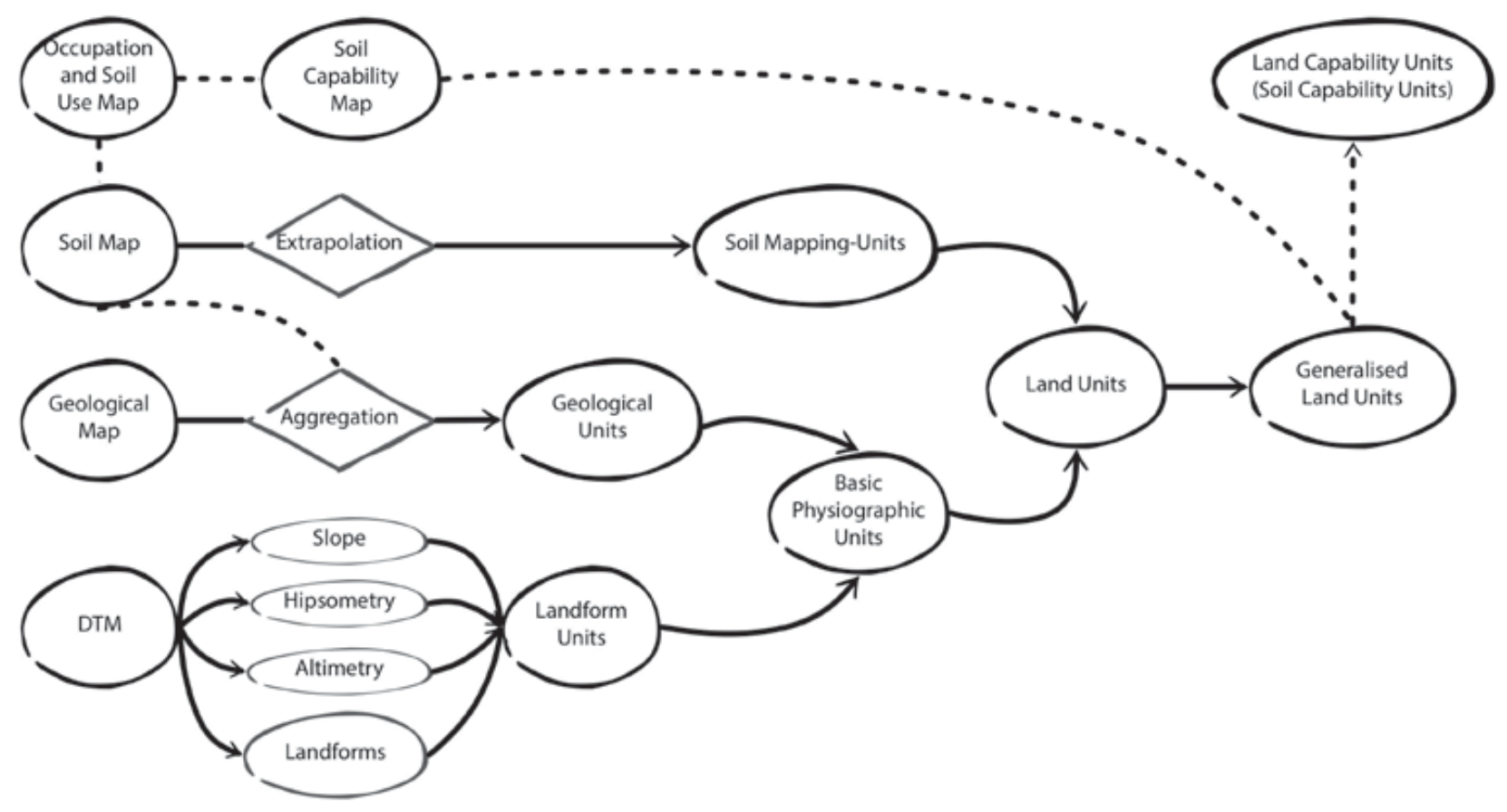

Fig. 2 - General flowchart for data reorganization and land unit delimitation.

Fig. 2 - Fluxograma geral do tratamento de dados e delimitação das unidades de terra.

\subsection{Lithological units}

Geological information was gathered from the geological map of Portugal (1:50 000) - sheets 26-D (Caldas da Rainha - Zbyszweski \& Almeida, 1960a, 1960b), 26-C (Peniche - França, Zbyszewski, \& Almeida, 1960a; França, Zbyszewski, \& Almeida, 1960b), 30-A (Lourinhã - Manuppella, Antunes, Pais, Ramalho, \& Rey, 1999a; Manuppella, Antunes, Pais, Ramalho, \& Rey, 1999b) and 30-B (Bombarral - Zbyszewski, 1966a, 1966b). The sheets were appended, in order to obtain a geologic map of the study area. These sheets show a distinct legend and content, thus a lithological map was derived from a simplification and aggregation of the existing 22 geological formations, aiming to reach the closest uniformity to lithological units. Lithological units were delineated through the similarity described on top of the lithological formations following the criteria of its topographical position, texture of the detrital or clastic sedimentary rocks and moreover the nature or composition of the rocks (calcareous or not calcareous). For the lithological unit delimitation information from the Portugal soil map regarding the alluvial and colluvial areas was also used. This was due to the fact that the alluvial areas in the geological map did not coincide with those in the soil map. Firstly, because the geological map and the soil map have different scales; secondly, because some alluvial areas of the geological map are colluvial areas according to the soil map. Hence, it was preferable to use the alluvial and colluvial areas of the soil map for the land unit delimitation. Finally, some information on the characteristics of the soil units (e.g. texture) was also jointly used with the grain size of rocks regarding different geological formations. 


\subsection{Landform units}

A digital terrain model (DTM) was prepared by projecting data from Shuttle Radar Topography Mission (SRTM) into the ETRS89-TM06 reference system, using bilinear resampling to a 30 meter pixel resolution. This DTM was used to identify the landform types based on the Hammond (1954, 1964a, 1964b) methodology, following the procedures specified by Morgan and Lesh (2005). The analysis was implemented in ArcGis using ESRI modelbuilder, as implemented by Mendes (2010). To run the model it was necessary to define a parameter of the focal statistics tool, the pixel radius circular window. That is, the pixel radius that determined the number of cells within a certain circular neighbourhood surrounding each pixel; this tool allows to calculate the percentages needed in the estimation of the various parameters (Morgan \& Lesh, 2005). In this case, a 15 pixel radius was used because it was considered to be the most appropriate for the scale of this study.

According to the procedures specified by Morgan and Lesh (2005), the landform analysis is divided in four sub-models, three of them are related with the parameters set by Hammond (1954, 1964a, 1964b) as means to determine three different characteristics which are determinant in land form analysis - near-level areas, local relief and profile type - and the fourth sub-model reclassifies the results of the first three sub-models based on the local interpretation according to the field observations. Firstly, the percentage of near- level areas is considered - corresponding to areas presenting slope values below $8 \%$ - and later a first landform type will be described as "Flat to nearly flat sloping", which consists of landforms predominantly dominated by near-level areas. Later, the local relief and profile type sub-models will assist in the delimitation of different landform types as, for instance, the "gently sloping" areas, which can be further divided into "gently sloping lowlands" and "gently sloping uplands", differentiating the surfaces according to its concavity/convexity (Mendes, 2010). Finally, the last sub-model will consist of a reclassification of the different areas obtained by the combination of the previously mentioned attributes (near-level areas, local relief and profile type), in order to obtain a final map of aggregated landform types. The geological formations were used to support the landforms delimitation.

\subsection{Soils}

Information regarding soil was taken from the Portuguese soil map (1:25 000) sheets 337, 338, 349, 350, 361 e 362 (Direcção-Geral da Agricultura e Desenvolvimento Rural, DGADR). The information of the Portugal soil map (SROA, 1973; IHERA, 1999) was extrapolated to the WRB (2006) system as shown in table I. In the first column are represented the identification numbers of which the general soil mapping unit obtained as a result. Some soil mapping units are marked with $\left({ }^{A}\right)$ as they may include small areas of Leptosols and eventually Luvisols and Vertisols; with $\left({ }^{\mathrm{B}}\right)$ in general can be qualified as calcic; and with $\left(^{\mathrm{C}}\right)$ may include small areas of Luvisols and Vertisols. Also, for 
each of the soil families an indication is given of the various soils phases as (a) agropedic phase; (d) shallow phase; (h) hydromorphic phase; (i) flooded phase; (p) stony phase. It should be emphasized that the delimitation of soil map units in the Portuguese soil map was not supported by the previous delimitation of basic physiographic units (landforms). Also, soil units identified in the study area generally reflect their relationship with the local soil parent material, and are not framed in the report of the geological map.

Table I - Correspondence between soil families (Portugal Soil Classification, PSC; IHERA, 1999) and the Reference Soil Groups (WRB, 2006) in the Lourinhã municipality, and symbols of the resulting general soil-mapping units.

Quadro I - Correspondência entre as famílias de solos (Classificação dos Solos de Portugal; IHERA, 1999) e os Grupos de Solos de Referência (WRB, 2006) no município de Lourinhã e símbolos das unidades cartográficas gerais resultantes.

\begin{tabular}{|c|c|c|}
\hline Soil-mapping units ID & Soil Families (PSC) & $\begin{array}{l}\text { Reference Soil } \\
\text { Groups (WRB) }\end{array}$ \\
\hline $1^{\mathrm{A}}$ & $\begin{array}{l}\text { Art; Ba; Lpt; Lpt(a); Lpt(a,h); Lpt(a,p); Lpt(p); Lvt; Lvt(a); Lvt(p); } \\
\text { Paco(a); Pago; Pago(a); Pao; Pao(a); Patc(a); Pato; Pato(a); } \\
\text { Pato(a,h); Pato(a,p); Ppt; Ppt(a);Ppr; Ppr(p);Pto; Vago; Vago(a); } \\
\text { Vao(a);Vato; Vato(a);Vt(a);Vt(a,p);Vt(d);Vt(p);Vto(a) }\end{array}$ & $\begin{array}{l}\text { Regosols, } \\
\text { Cambisols. }\end{array}$ \\
\hline 2 & $\begin{array}{l}\text { Arc; Arct; Ec; Pcdc; Pcdc(a); Pcdc(a,p); Pcdc(p); Pcdc'(a); } \\
\text { Pcsd(a); Pcsd'(a); Pcst; Pcst'; Pcst'(a); Pcst'(h); Vcst; Vcst(a); Vcd; } \\
\text { Vcd(p); Vcdc(a) }\end{array}$ & $\begin{array}{l}\text { Regolsols }^{\mathrm{B}} \text {, } \\
\text { Calcisols, } \\
\text { Leptosols }{ }^{\mathrm{B}} \text {. }\end{array}$ \\
\hline $3^{\mathrm{C}}$ & $\begin{array}{l}\text { Bva; Pagc; Pc; Pcs; Pcs'; Pcs'(a,d,p); Spc(p); Spc'; Svc'; Vac'; } \\
\text { Vac'(a) }\end{array}$ & Calcisols, Regosols ${ }^{\mathrm{B}}$. \\
\hline 4 & $\begin{array}{l}\text { A; A(h); A(i); Aa; Aac; } \operatorname{Aac}(\mathrm{h}, \mathrm{i}) ; \operatorname{Ac} ; \operatorname{Ac}(\mathrm{h}) ; \operatorname{Al}(\mathrm{h}) ; \operatorname{Alc}(\mathrm{h}) ; \operatorname{At} \\
\operatorname{At}(\mathrm{h}) ; \operatorname{At}(\mathrm{p}) ; \operatorname{Atl} ; \operatorname{Atl}(\mathrm{a}) ; \operatorname{Atl}(\mathrm{h}) ; \mathrm{Ca} ; \mathrm{Cal} ; \operatorname{Calc}\end{array}$ & Fluvisols. \\
\hline 5 & Sbl(h); Sb; Sb(a); Sb(h); Sba; Sbac; Sbc; Sbl; Sbl(a,h) & Regosols, Fluvisols. \\
\hline 6 & $\mathrm{Rg} ; \mathrm{Rgc}$ & Arenosols. \\
\hline 7 & Ap; Ap(a); Pz; Pz(a) & $\begin{array}{l}\text { Arenosols, } \\
\text { Regosols, Podzols. }\end{array}$ \\
\hline Social Area & Asoc & Social Area. \\
\hline
\end{tabular}

Several difficulties emerged with the analysis of soil data. The scale (1:25 000) suggests a detailed soil map, but it presents great spatial variability related to the soil parent material, as designations such as "fine sandstones, clays and claystones" or "fine and coarser interstratified sandstones" are used. Many soil units presented in the soil map of Portugal are distinguished generally by the color, which is not necessarily related to different physical and chemical characteristics. Several soil units considered in the soil map of Portugal are absent in the PSC Handbook (SROA, 1973), lacking therefore a general morphological description and a typified characterization (such as thickness and effective soil depth, horizons, texture, concentration of calcium carbonate, complex exchange characteristics...) other than their designation (IHERA, 1999). Although characteristics of some soil units in the soil map are shown in the PSC Handbook (SROA, 1973), morphological and analytical characterization details for the same units occurring in the area 
under study are not known. Given these difficulties in establishing reliable inferences, it was only possible to consider general aspects of the relation between the soil parent material and the different soil units presented in the soil map. There were two options: either considering the lithological information from the soil map or the general lithological units obtained from the geological map. The authors opted for the second one, in order to acquire a result that could be referenced to the geological information available but also because the designations of the soil parent material suggest a great heterogeneity and would bring even more subjectivity to the results. Consequently, the criteria used to define the soil-mapping units (Reference Soil Groups sensu WRB, 2006) were mostly associated with the possible soil profile differentiation, the calcium carbonate occurrence, the nature of limestone rocks and the topographical position. The different soil types were transferred from one system to the other according with the correlations of diagnostic soil horizons established by Sousa, Madeira, \& Monteiro (2004) and also taking into account the studies carried out by Gomes (1978), Madeira (1986) and Marques (2010). It is noteworthy that the soil information available is not sufficient for an accurate soil classification at first level within the WRB (2006) system.

\section{Land units}

In the present case study, the concept of basic physiographic units, a concept already developed in some soil maps of Portugal (Agroconsultores \& Coba, 1991; Agroconsultores \& Geometral, 1995), was used to support the delimitation of land units. These units resulted from the intersection of lithological units and landform types; after the intersection it was also necessary to eliminate the small sliver polygons that resulted from the intersection. In this case, the authors opted to eliminate all polygons with an area under 11 ha and associate them with the biggest adjacent area. Such polygons were eliminated because their shape/area did not make sense for practical terms, being interpreted as "noise".

The basic physiographic units were used to frame the information regarding soils and rock outcrops in order to delimitate the land units. Moreover, the predominant soil mapping units within each land unit were also considered, as well as the presence/absence of rock outcrops Therefore, information regarding soils was only framed on the basic physiographic unit polygons based on the most relevant soil types inside each polygon. Information regarding rock outcrops was framed using the soil capability map and confirmed by field observations.

After framing the information concerning the soil attribute and presence or absence of rock outcrops with the basic physiographic units, land units were obtained as a result. Thus, land units were described by geology, landforms, soils and presence/absence of rock outcrops. Additionally, the resulting land units had to be generalized in order to compare them with the soil capability map. Thus, the texture and hardness of the lithological materials, topographical position and presence of rock outcrops were used as criteria for land unit assessment. 


\section{RESULTS}

\section{Lithological units}

As reported in table II and figure 3, eleven lithological units resulted from the aggregation of the geological formations reported in the geological map of Portugal. The A lithological unit includes the alluvial areas surrounding the main watercourse network, and is defined by its topographical position and comprises an area of 1,454.73ha.

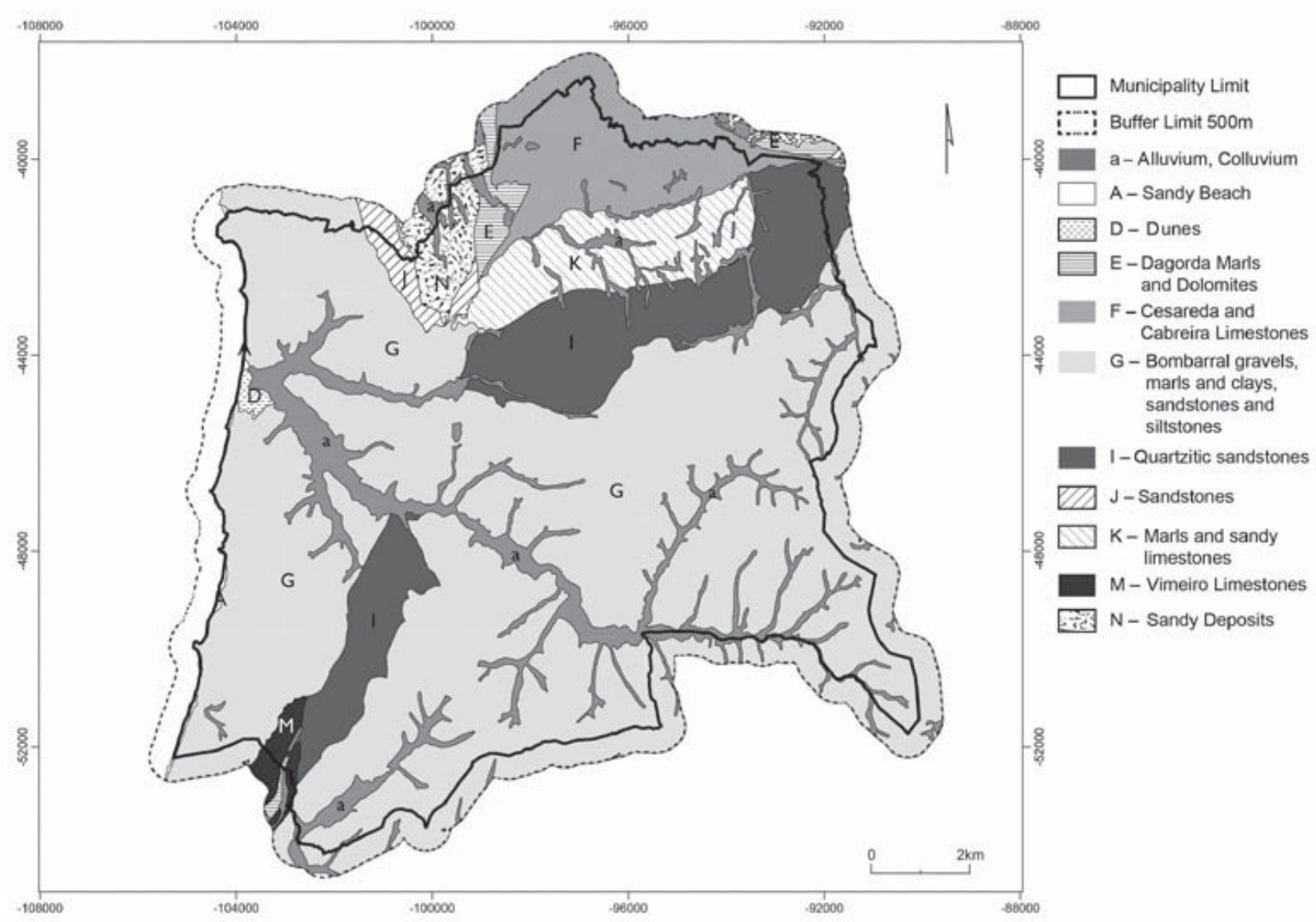

Fig. 3 - Distribution of the general lithological units.

Fig. 3 - Distribuição das unidades geológicas gerais.

The A (24.9ha) and D (38.1ha) lithological units are defined by its location and are associated with sandy beach and dunes, respectively. The E lithological unit corresponds to Lourinhã's oldest geological formation (Dagorda marls and dolomites), covering an area of 109.2ha.

Both the $\mathrm{F}$ and $\mathrm{K}$ lithological units are located in the Cesareda plateau and are distinguished from each other by the nature of their lithological materials; the former (860.6ha) includes calcareous formations in thick benches, while the latter (752.2ha) comprises marls and sandy limestones. 
Unit $\mathrm{G}$ is the largest unit of the area (9,240.5ha) and includes materials corresponding to sandstones (variable grain size), marls, and some formations composed by clays and siltstones, and gravels.

Unit I ( $1,835.1$ ha) marks the transition between the $\mathrm{G}$ and $\mathrm{K}$ lithological units. This unit is distinct from the former $\mathrm{G}$ presenting an apparently homogeneous texture composed by quartzitic sandstones, and from unit $\mathrm{K}$ by the absence of calcareous materials.

In the southern part of the Lourinhã municipality area, the $\mathrm{M}$ lithological unit includes another calcareous formation (Vimeiro limestones), comprising an area of 69.7ha.

Finally, the $\mathrm{N}$ and J units, located in the typhonic valley of Bolhos (Manuppella et al., 1999b), distinguished themselves by the consolidation and maybe grain size of the lithological formations: unit $\mathrm{N}$ (206.1ha) corresponds to sandy deposits, whereas unit J (125.5ha) is associated with sandstones.

Table II - Description and areas of the lithological units defined for the Lourinhã municipality.

Quadro II - Descrição geral e áreas das unidades litológicas definidas para o concelho de Lourinhã.

\begin{tabular}{|c|c|c|c|}
\hline Lithological units ID & General description & Area (ha) & Area $(\%)$ \\
\hline$a$ & Alluvium, Colluvium & $1,454.7$ & 9.9 \\
\hline A & Beach sands & 24.9 & 0.2 \\
\hline $\mathrm{D}$ & Dunes & 38.1 & 0.3 \\
\hline $\mathrm{E}$ & Dagorda marls and dolomites & 109.2 & 0.7 \\
\hline $\mathrm{F}$ & Cesareda and Cabreira limestones & 860.6 & 5.8 \\
\hline G & Bombarral gravels, marls and clays, sandstones and siltstones & $9,240.5$ & 62.8 \\
\hline I & Quartzitic sandstones & $1,835.1$ & 12.5 \\
\hline $\mathrm{J}$ & Sandstones & 125.5 & 0.8 \\
\hline $\mathrm{K}$ & Marls and sandy limestones & 752.2 & 5.1 \\
\hline M & Vimeiro limestones & 69.7 & 0.5 \\
\hline \multirow[t]{2}{*}{$\mathrm{N}$} & Sandy deposits & 206.1 & 1.4 \\
\hline & Total & $1,4716.6$ & 100.0 \\
\hline
\end{tabular}

\section{Landforms}

The aggregated landform types resulting from the landform analysis model are described in table III and represented in figure 4 . The landform description was given according to the prevalent slope gradient class.

Table III - Characteristics and areas of the major landforms.

Quadro III - Características e áreas das formas de relevo principais.

\begin{tabular}{llrrr}
\hline Landform units ID & \multicolumn{1}{c}{ Description } & $\begin{array}{c}\text { Slope gradient } \\
\text { classes present }\end{array}$ (\%) & Area (ha) & Area (\%) \\
\hline F & Flat to nearly flat sloping & $\underline{0-5} ; 5-8$ & $5,020.6$ & 34.1 \\
S & Gently sloping & $\underline{5-8} ; 8-12$ & $5,319.8$ & 36.2 \\
Ss & Strongly sloping & $\underline{8-12 ; 12-16}$ & $3,890.9$ & 26.4 \\
St & Steep slopes & $\underline{16-25}>25$ & 485.3 & 3.3 \\
\hline & & Total & $1,4716.6$ & 100.0 \\
\hline
\end{tabular}

* The underlined represents the prevalent slope gradient class 
The landform class flat to nearly flat sloping, occupying 5,020.6ha, includes alluvial and colluvial areas as well as its surrounding areas; also, it includes the Cesareda plateau, where several colluvial/alluvial areas occur, and the area corresponding to the typhonic valley of "Bolhos" with sandy materials.

The landform class gently sloping, comprises the largest area of the municipality (5,319.8ha) and is related to the top areas corresponding to the ridgelines, where most of the settlement occurs.

The strongly sloping landform class is primarily associated with the fluvial incision shaping the valleys; it is largely associated with the Rio Grande watershed and occupies about 3,890.9ha.

Finally, the landform class steep slopes, has a smaller expression comprising $485.3 \mathrm{ha}$ of the municipality area. This class describes the areas along the coastline in transition to the cliffs and the cliffs themselves, and also areas sectioned by geological faults, as Cruz da Columbeira and Vila Verde faults (Manuppella et al., 1999b) that slice up the I lithological unit.

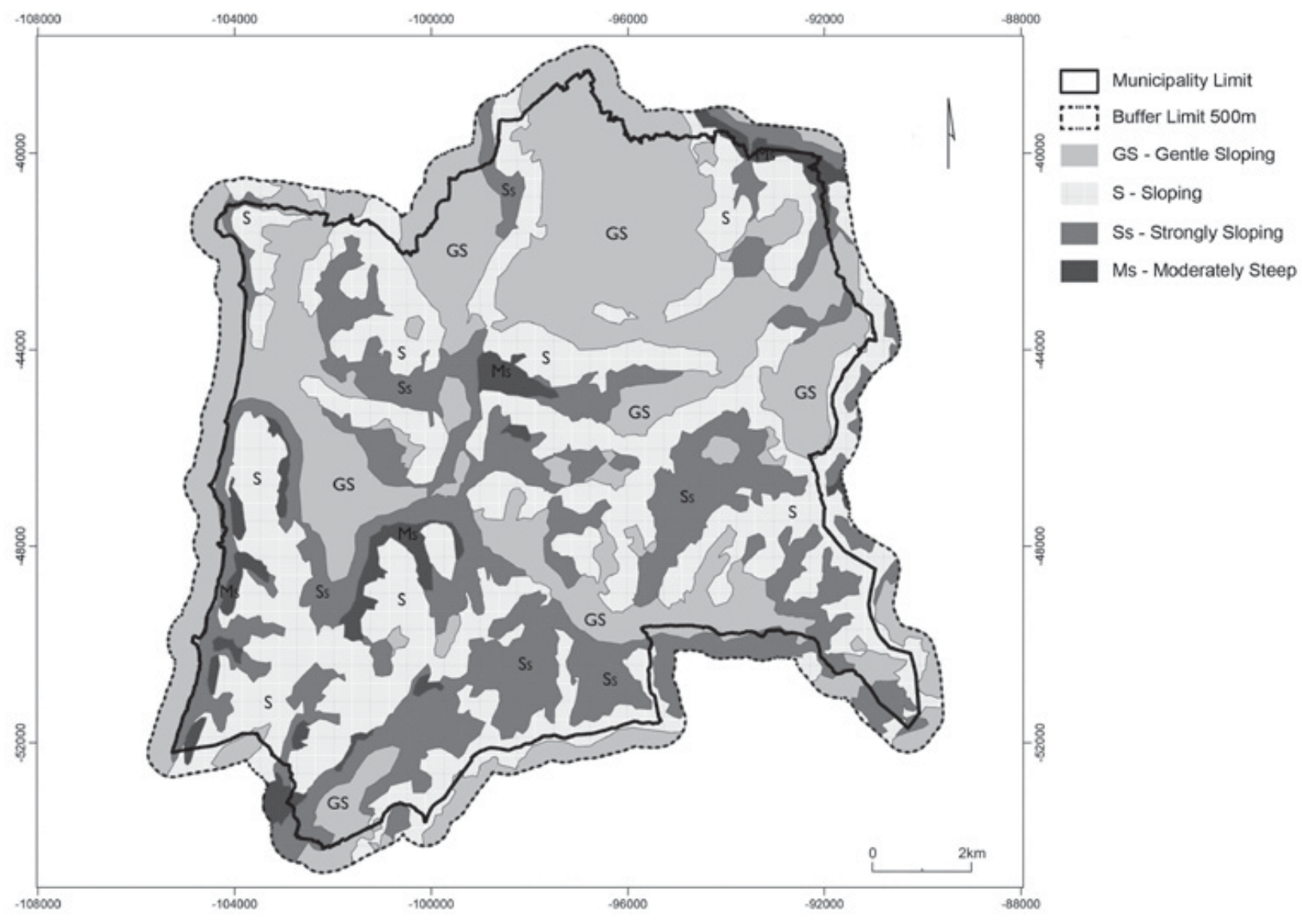

Fig. 4 - Distribution of the major landforms.

Fig. 4 - Distribuição das formas de relevo principais. 


\section{Soil-mapping units}

The distribution of resulting eight soil-mapping units is shown in figure 5. Unit 1, mostly composed by Regosols and Cambisols (table IV) is the largest soil-mapping unit in the Lourinhã municipality, occupying 9,394.5ha; small areas of Leptosols and eventually Luvisols and Vertisols may also occur. The cartographic information regarding these soil units suggests that the land use system has a strong influence on soil characteristics, as agropedic phases are frequent; in addition, mostly in the northern area of the municipality (Cesareda plateau), stony phases occur along with bedrock outcrops (fig. 9). The soils in this unit, generally present a coarse to medium or even fine texture, although local variations may occur since the parent material varies from fine sandstones, clays and mudstones, to coarser sandstones and related rocks (IHERA, 1999); also, erosion and/or landslide deposits and soil creep may also influence the soils of this unit, as it can be realized by some families' designations resulting from colluvial deposition (IHERA, 1999) and by references regarding landslide occurrences (Cipriano, 2001).

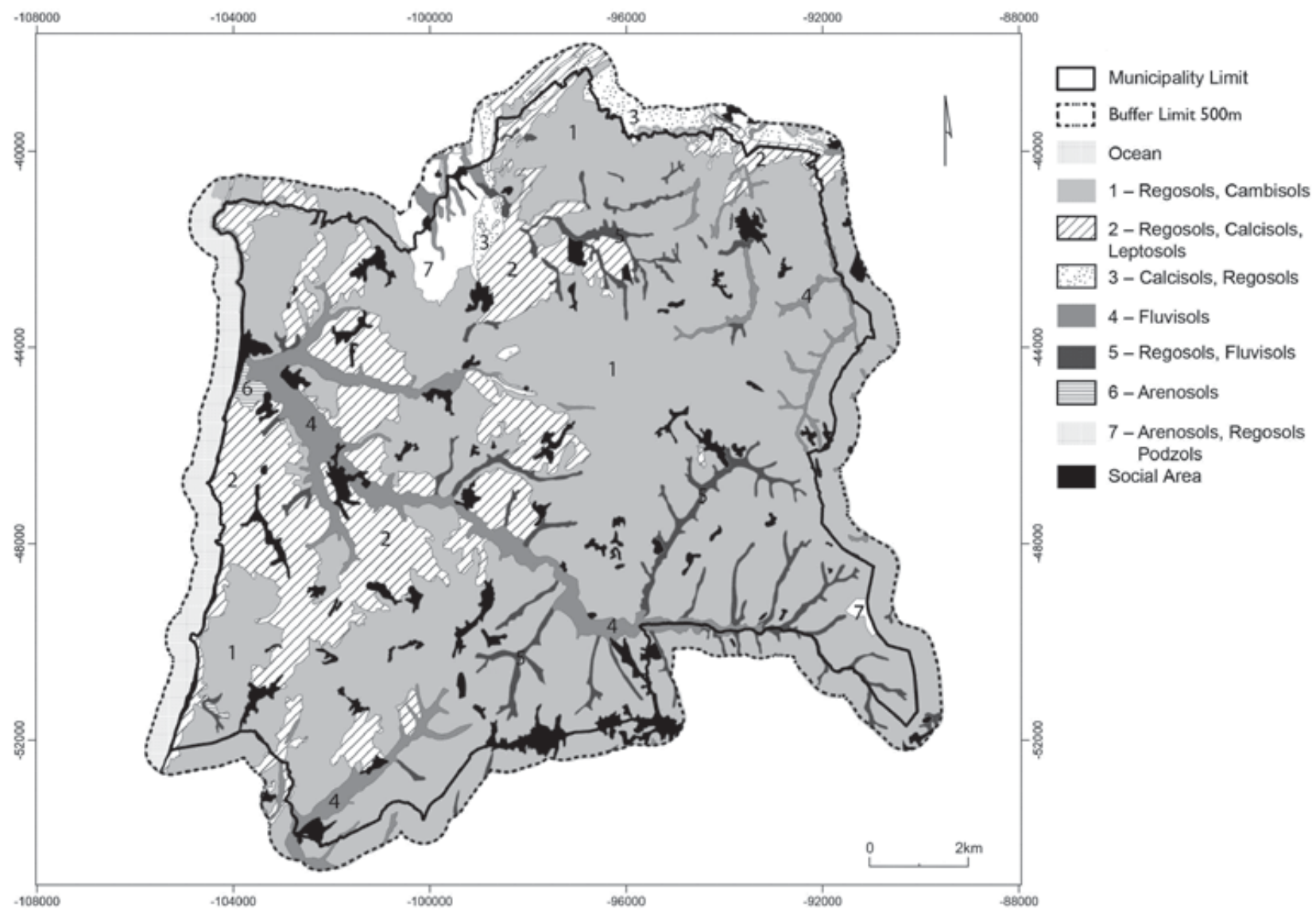

Fig. 5 - Distribution of the general soil-mapping units.

Fig. 5 - Distribuição das unidades cartográficas gerais de solos. 
Unit 2 covers 2,758.8ha and may include Regosols, Calcisols and Leptosols mostly developed on compact calcareous rocks; the Regosols and Leptosols may be qualified as calcic (sensu WRB, 2006) in some areas. Unit 3 (129.2ha) including Calcisols and Regosols (mostly calcic) is largely developed over non-compact calcareous materials, and is mostly located in the northern part of the municipality.

Unit 4 includes Fluvisols and occurs in alluvial areas (as designated in both geological and soil maps), whereas unit 5 (associated with Regosols and Fluvisols) occurs in colluvial areas (as designated in the soil map), which are mostly designated as alluvial areas in the geological map; these soil-mapping units together comprise 1,454.7ha.

Unit 6 (37.2ha) corresponds to Arenosols developed on sandy dune formations near the coast. Finally, unit 7 (222.5ha) includes Arenosols, Regosols and Podzols developed on the sandy formations, which filled the "Bolhos" typhonic valley.

Table IV - Constitution and areas of general soil mapping units.

Quadro IV - Constituição e áreas das unidades cartográficas gerais de solos.

\begin{tabular}{clrc}
\hline Soil-mapping units ID & \multicolumn{1}{c}{ Description } & Area (ha) & Area (\%) \\
\hline 1 & Regosols $^{\mathrm{A}}$, Cambisols & $9,394.5$ & 63.8 \\
2 & Regosols $^{\mathrm{B}}$, Cambisols, Leptosols $\mathrm{B}^{\mathrm{B}}$ & $2,758.8$ & 18.7 \\
3 & Calcisols, Regosols $^{\mathrm{B}}$ & 129.2 & 0.9 \\
4 & Fluvisols & 909.3 & 6.2 \\
5 & Regosols, Fluvisols & 545.4 & 3.7 \\
6 & Arenosols & 37.2 & 0.3 \\
7 & Arenosols, Regosols, Podzols & 222.5 & 1.5 \\
Social Area & Social Area & 719.7 & 4.9 \\
\hline
\end{tabular}

\section{Land units}

From the intersection between the landforms and lithological units, 33 basic physiographic units were delineated. As mentioned, after framing the soil attribute and the presence of rock outcrops to the basic physiographic units, 33 land units were defined. These resulting land units were then grouped in 11 general land units (table V, fig. 6). Although most of these units are explained by their topographical position, the texture of the lithological materials and presence of rock outcrops was also used as criteria for their aggregation.

Land unit 1 represents the alluvial and colluvial areas mostly located at lower altitudes with flat slopes, corresponding mainly to Fluvisols (and eventually Regosols), and comprising an area of 1,473.8ha; field observations indicate that this area is not intensively used for agriculture, possibly due to flooding events and to hydromorphic soil conditions affecting plant rooting. 
Unit 2 (27.4ha) is associated with the beach area, with sandy materials and flat slopes, whereas the land unit 3 is associated with Arenosols (over sand dunes) and occupies 36.9ha.

Unit $4(2,528.1 \mathrm{ha})$ occurs in the areas with gentle slopes adjacent to the main alluvial areas that are located on the slope base, and soils mostly correspond to Regosols (in part calcic) and Cambisols; drainage limitations may occur in this unit since some hydromorphic phases exist.

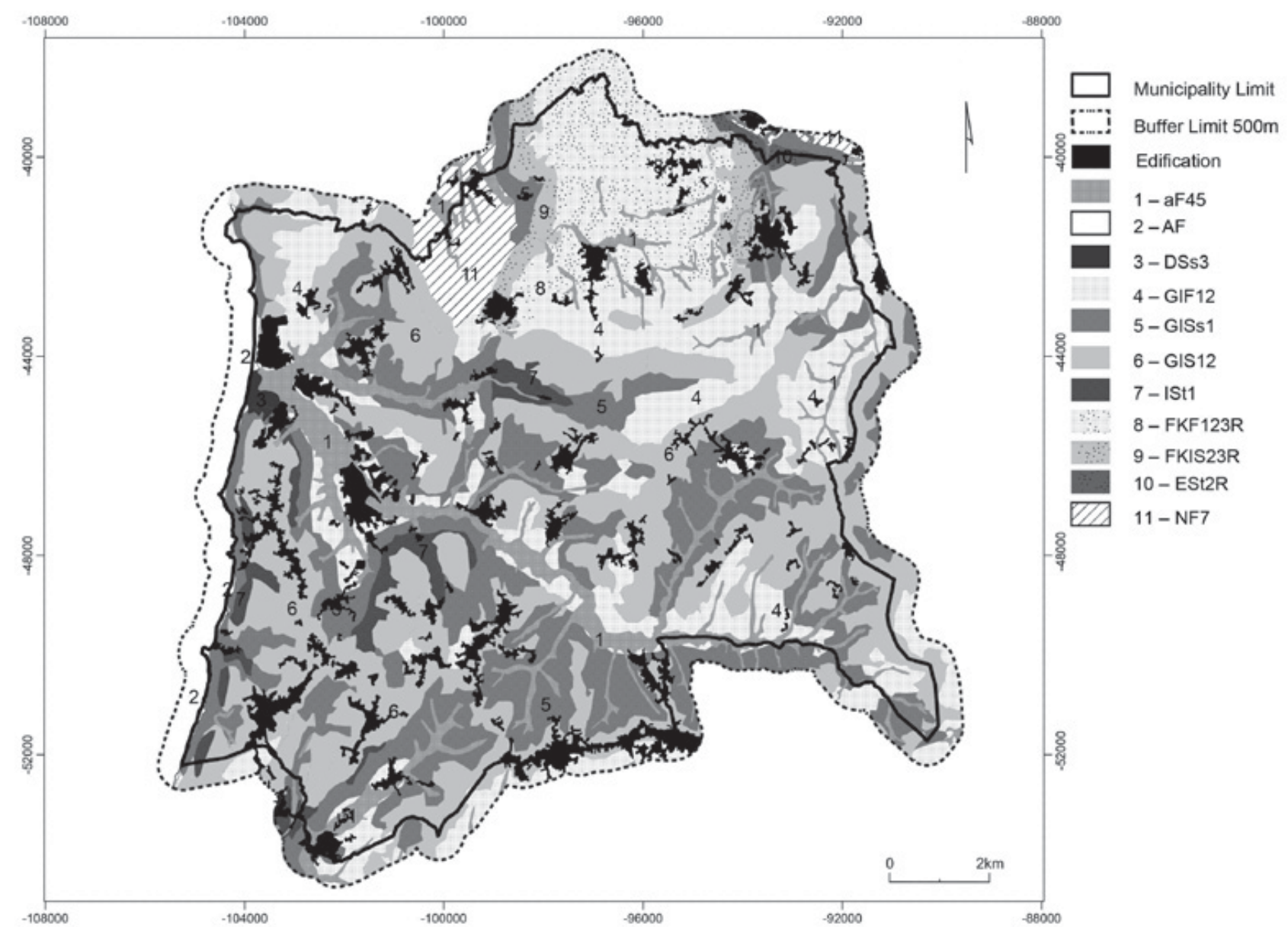

Fig. 6 - Distribution of the generalized land units.

Fig. 6 - Distribuição das unidades de terra generalizadas.

Unit $5(3,360.4 \mathrm{ha})$ represents the slope areas bordering the alluvial and colluvial areas and presents great grain size variability, corresponding mostly to Regosols, Cambisols and Leptosols, at a low extent; in this unit, erosion evidence was observed in some areas. 
Land unit 6, where most of the settlement is concentrated, is the largest unit of the area $(5,021.1 \mathrm{ha})$ and describes the top sloping areas that include the ridgelines, Regosols and Cambisols being dominant, and, calcic Regosols and Leptosols occur at a lower extent; this unit, as mentioned for unit 5 , presents great grain size variability associated with the parent materials corresponding to sandstones.

Table V - Attributes and areas of the land units.

Quadro V-Atributos e áreas das unidades de terra.

\begin{tabular}{cllclrrr}
\hline Land units ID & Composition & Geology & Landforms & Soils & Rocky outcrops & Area (ha) & Area (\%) \\
\hline 1 & aF45 & a & F & 4,5 & - & $1,473.8$ & 10 \\
2 & AF & A & F & - & - & 27.4 & 0.2 \\
3 & DSs3 & D & Ss & 3 & - & 36.9 & 0.3 \\
4 & GIF12 & G, I & F & 1,2 & - & $2,528.1$ & 17.2 \\
5 & GISs1 & G, I & Ss & 1 & - & $3,360.4$ & 22.8 \\
6 & GIS12 & G, I & S & 1,2 & - & $5,021.1$ & 34.1 \\
7 & ISt1 & I & St & 1 & - & 387 & 2.6 \\
8 & FKF123R & F, K & F & $1,2,3$ & R & $1,160.6$ & 7.9 \\
9 & FKIS23R & F, K, I & S & 2,3 & R & 375.1 & 2.6 \\
10 & ESt2R & E & St & 2 & R & 29.3 & 0.2 \\
11 & NF7 & N & F & 7 & - & 316.9 & 2.1 \\
\hline
\end{tabular}

Unit 7 is mainly located along the coast representing the cliffs and areas sectioned by geological faults and it describes exceptional situations of steep slopes, where Regosols, Cambisols and Leptosols may occur. It comprises an area of 387ha.

Unit $8(1,160.6 \mathrm{ha})$ is located in the Cesareda plateau and represents the areas with gentle slopes where limestone formations occur and the presence of rock outcrops (not clear by the information reported in the soil map; fig. 5 and table IV) is a main landscape feature (fig. 7); soils mostly correspond to Regosols and Cambisols, but Calcisols and calcic Regosols may also occur in small areas. 


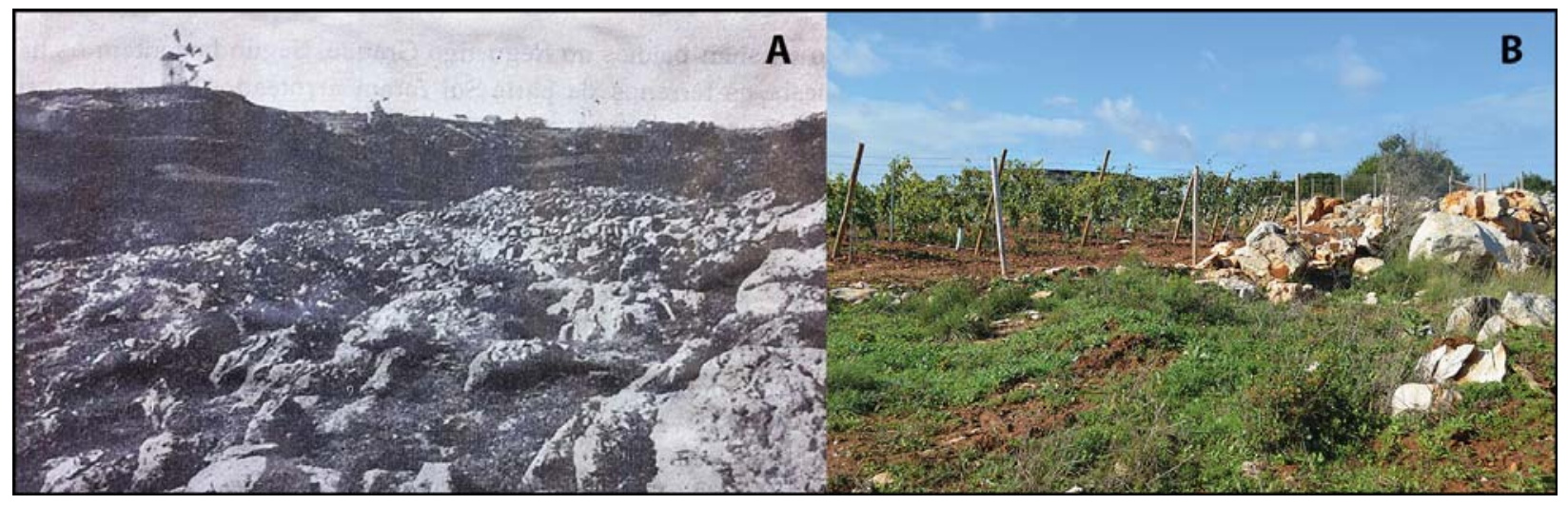

Fig. 7 - (A) Rock outcrops in Cesareda plateau (Ribeiro, 1940); (B) Removal of rock outcrops in the Cesareda plateau for a vineyard installation. Colour figure available online.

Fig. 7 - (A) Afloramentos rochosos no planalto da Cesareda (Ribeiro, 1940). (B) Remoção de afloramentos rochosos no planalto da Cesareda para a instalação de uma vinha. Figura a cores disponível online.

The land units 9 and 10 are also located in the Cesareda plateau, likewise they have a significant presence of rock outcrops. Unit 9 (375.1ha), associated with Calcic Regosols, Regosols, Cambisols, Calcisols and Leptosols, describes the sloping areas, while unit 10 (29.2ha), associated with Regosols (partially calcic), Cambisols and Leptosols (partially calcic), describes areas with steep slopes.

Finally, the land unit 11 (316.9ha) corresponds to a gentle sloping landform and is associated with a mosaic of Arenosols, Regosols and Podzols developed on the sandy deposits located in the "Bolhos" typhonic valley.

\section{DISCUSSION}

The applicability of the land unit concept involved a certain complexity given the type and quality of the available biophysical data for the area under study. Firstly, difficulties arose from the scale and legend heterogeneity of the geological map, and strong uncertainty may exist regarding the top of the lithological formations as a result of the sedimentary nature of geological formations and also due to the fact that their description is primarily related with the age or deposition environments rather than lithological differentiation; that is, a strong heterogeneity of soil parent material is expected. Secondly, the land unit delimitation process endorsed the recognition of strong deficiency of information on basic characteristics of soil units and therefore a limiting capacity to establish their classification; also, the rockiness (boulders and outcrops of bedrock material) was not revealed in the soil map and was confounded by the stoniness (coarse fragments). Although the presence of bedrock outcrops (as a soil characteristic) is indicated in the soil capability map, it did not overcome the deficiency (and inadequacy) of information provided by the soil map (1:25 000) (fig. 8, table I). 


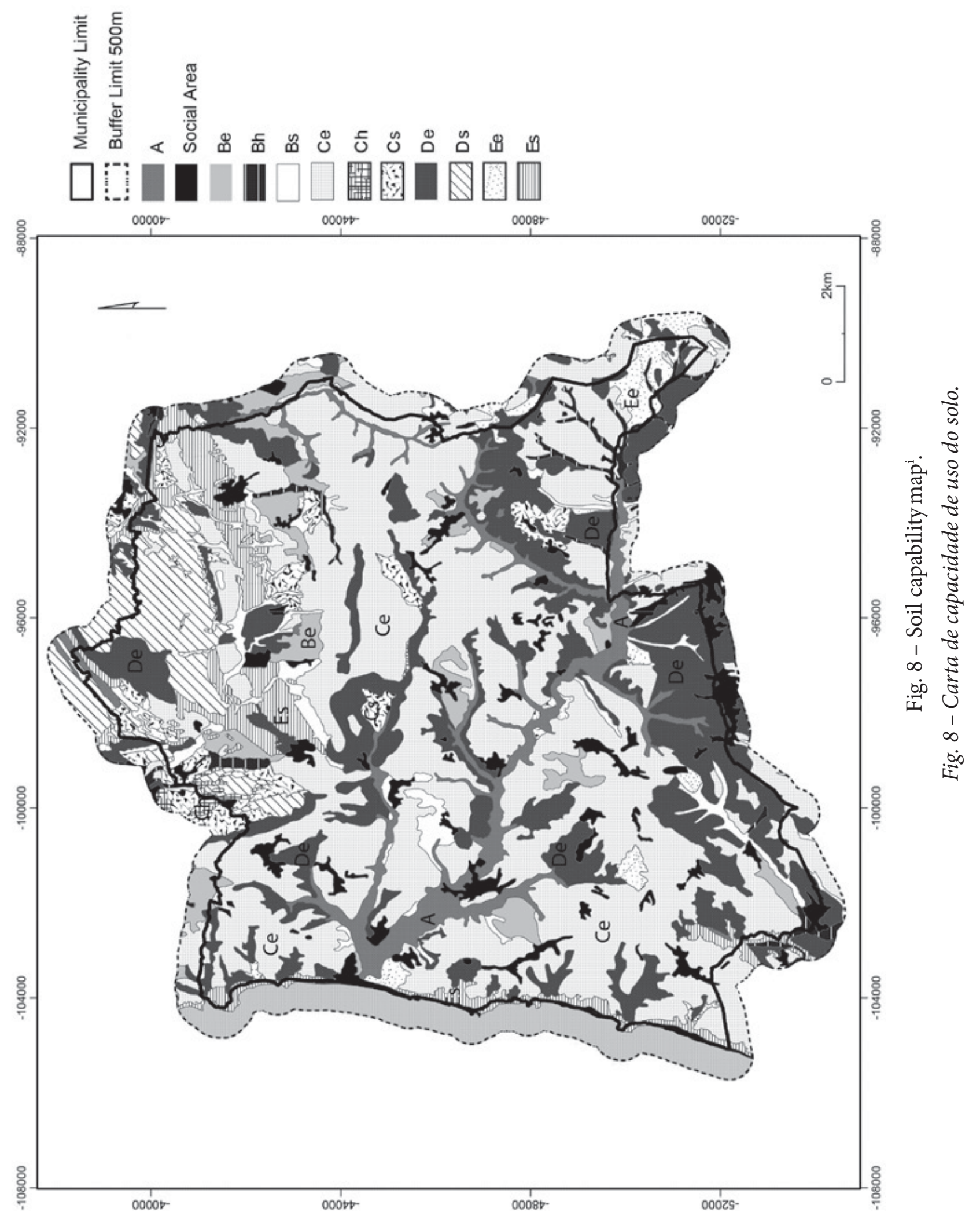


The reorganization and improvement of information following the land unit assessment creates conditions for a deeper understanding of the land characteristics and qualities which may support the land capability and land suitability classification, enabling an adaptation of methodologies already used in other regions for the whole country (Agroconsultores \& Coba, 1991; Agroconsultores \& Geometral, 1995; Agroconsultires \& Geometral, 2004). That is, the land unit approach may be a useful tool to support land planning decisions (at different scales) and legislation (RAN) using identical criteria.

Our study indicates some similarity between the land units and the distribution of some soil capability classes and subclasses (figs. 6 and 8). For example, land unit 1 largely coincides with areas of the A soil capability class and some areas of the Bh and Bs subclasses (figs 6 and 8); also, Ds and ES subclasses largely coincides with the land units 8 and 9 . However, our study also suggests that the landscape discrimination by the land unit approach is more detailed than that corresponding to the distribution of soil capability classes and subclasses, as shown in the soil capability map (fig. 8). For example, the Ce soil capability subclass comprising 6,751.7ha (about $45.9 \%$ of the total area; table VI) corresponds to the largest area of the Lourinhã Municipality, and includes mostly areas of land units 4 and 6 and areas of land unit 5 (figs. 6 and 8). This suggests that the land unit delimitation, following an improved framework of permanent biophysical features of the land, may facilitate a deeper land capability assessment (soil capability classes). Similar considerations could be developed for the De soil capability subclass.

According to the Soil Capability Handbook of Portugal (SROA, 1972), the subclass Ce corresponds to areas with severe limitations regarding erosion risks, with slopes up to $25 \%$ and limited effective soil depth $(>25 \mathrm{~cm}$ ), and may be used for occasional cropping. Nevertheless, the areas of the subclass Ce (soil capability map; fig. 8) mostly correspond to those of land units 4, 6 and 5, where the dominant slope gradient classes are $0-5 \%, 5-8 \%$ and $8-12 \%$, respectively (fig. 6 and table III). Although some soils in such subclass areas may show an effective depth lower than $50 \mathrm{~cm}$, most of them have an effective depth greater than $50 \mathrm{~cm}$ (SROA, 1973), and therefore could be considered in the Be capability subclass (slope up to $15 \%$ and effective soil depth $>35 \mathrm{~cm}$ ); also, most areas of those land units could be included in the A2 land suitability established by Agroconsultores \& Geometral (1995) for Entre Douro e Minho for areas where slopes may range up to $15 \%$ and the effective soil depth is at least $50 \mathrm{~cm}$. Indeed, in field observations it was observed that most of the Ce subclass areas are intensely used for agriculture, as opposed to what is considered for the Ce soil capability subclass (SROA, 1972). As long as agricultural management practices are implemented to control the erosion processes, such areas may not show biophysical constraints to be classified as Ce. Similar considerations could be outlined for most of the areas classified in De soil capability subclass (figs. 6 and 8). 
Table VI - Soil capability classes and subclasses in the Soil Capability Map ${ }^{\mathrm{i}}$ corresponding to the Lourinhã municipality (soil limitation degree increases from A to E).

Quadro VI - Classes e subclasses de capacidade de uso na Carta de Capacidade e Uso do Solo do município de Lourinhã (o grau de limitação do solo aumenta de A para E).

\begin{tabular}{llrc}
\hline \multicolumn{1}{c}{$\begin{array}{c}\text { Soil capability } \\
\text { classes and subclasses }\end{array}$} & Soil use limitations & Area (ha) & Area (\%) \\
\hline A & Few limitations & 881.9 & 6.0 \\
Be & Erosion and runoff & 558.2 & 3.8 \\
Bh & Excess water & 162.1 & 1.1 \\
Bs & Root zone limitations & 517.9 & 3.5 \\
Ce & Erosion and runoff & $6,751.7$ & 45.9 \\
Ch & Excess water & 25.6 & 0.2 \\
Cs & Root zone limitations & 420 & 2.8 \\
De & Erosion and runoff & $3,071.1$ & 20.9 \\
Ds & Root zone limitations & 598.1 & 4.1 \\
Ee & Erosion and runoff & 292.2 & 1.9 \\
Es & Root zone limitations & 718.1 & 4.9 \\
Social Area & & 719.7 & 4.9 \\
\hline Total & & $1,471.661$ & 100.0 \\
\hline
\end{tabular}

According to the soil capability map, only $14.4 \%$ of the area (6\% of class A and $8.4 \%$ of class B) is well suited for intensive cropping and grazing activities; however, most of this land is not used for intensive cropping, which may be associated with flooding susceptibility and drainage limitations in some areas, as suggested by the hydromorphic and flooding phases reported in the soil map (table I). Therefore, considering that the subclass Ch only occupy $0.2 \%$ of the municipality area (table VI), only $14.6 \%$ of the area would be, in principle, considered within the National Agricultural Reserve (according to the Ministerial Order $n^{\circ} 73 / 2009,31^{\text {st }}$ March). As mentioned, large areas of the Lourinhã municipality, especially those corresponding to land units 4, 6 and 5, could be positioned in the B capability class (mostly Be subclass), or in A2 suitability class (moderate suitability for agricultural crops) established for The Entre-Douro e Minho region (Agroconsultores \& Geometral, 19995). Consequently, following the same Ministerial Order $\mathrm{n}^{\circ} 73 / 2009,31^{\text {st }}$ March, that recognizes that "are part of the RAN the land units that present a high or moderate suitability for agriculture", it is concluded that RAN areas could reach a high proportion of the municipality area, as the proportion of those land units reach about $74 \%$ (table $\mathrm{V}$ ). This large discrepancy is clearly associated with the fact that the soil capability units were not delimitated within a framework of land units, with most of the area considered to have steep slopes (Ce subclass). In short, the land unit delimitation may allow an improved framework of the soil capability classes and subclasses as well as an improved outline to identify and delimitate RAN areas.

Land physical limitations in the Lourinhã municipality are mostly associated with erosion, rockiness, drainage/flooding and climate. Meanwhile, the area may be largely prone to erosion susceptibility, as about $72.5 \%$ (table VI) of the area is included in erosion subclasses of different classes. Although the apparent contradiction with aforementioned considerations regarding land capability classification, it should be emphasized that ero- 
sion (sheet and rill erosion) is common and pronounced even in areas with gentle slopes (as land unit 6 with a prevalent slope gradient between 5-8\%), as recognized by field observations (fig. 9).

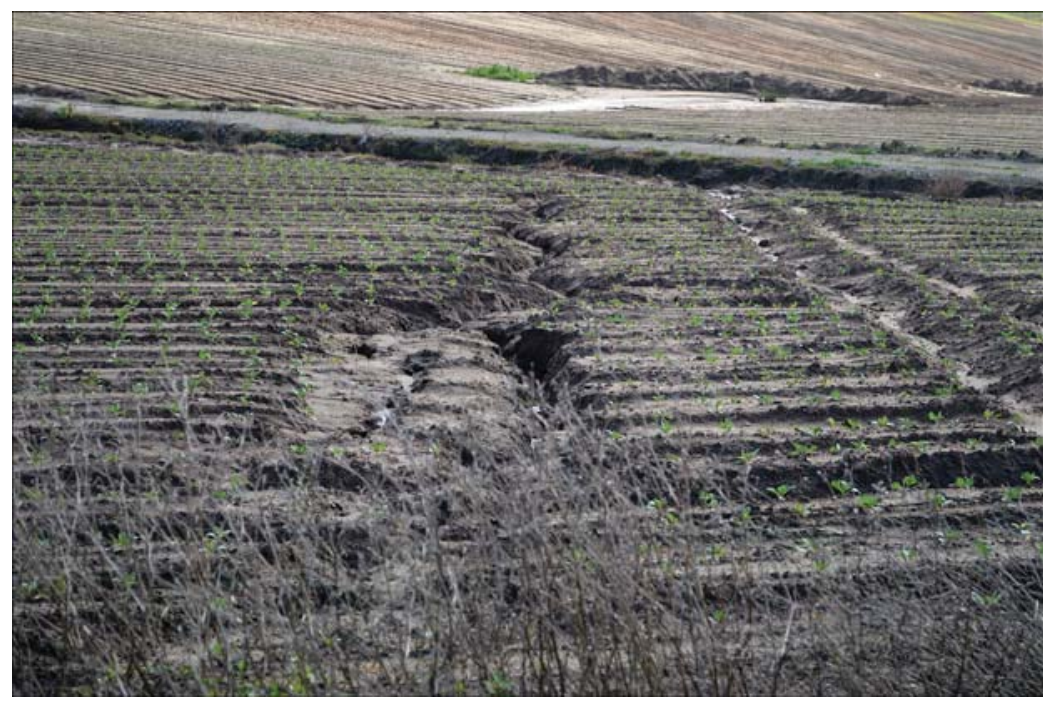

Fig. 9 - Soil erosion observed during the field observations. Colour figure available online.

Fig. 9 - Evidência de erosão observada durante o trabalho de campo. Figura a cores disponível online.

Besides the soil erodibility and the slope angle, soil erosion is also associated with the removal of hedgerows, stonewalls and other fences (delimitating land parcels) for easier crop management, resulting in an increment of slope length and uniformity, and with reduction of soil protection (fig. 10). That is, despite the slope and soil erodibility effects, erosion susceptibilities in the municipality of Lourinhã are strongly related to the great changes in the land use system and the absence of required conservation measures. Also, landslides and soil creep should be also taken into account for land capability purposes, as Cipriano (2001, p. 111) reported that "the nature of the clay soils may be the cause of the population's decay, as prolonged rains create landslides that drag everything with it".

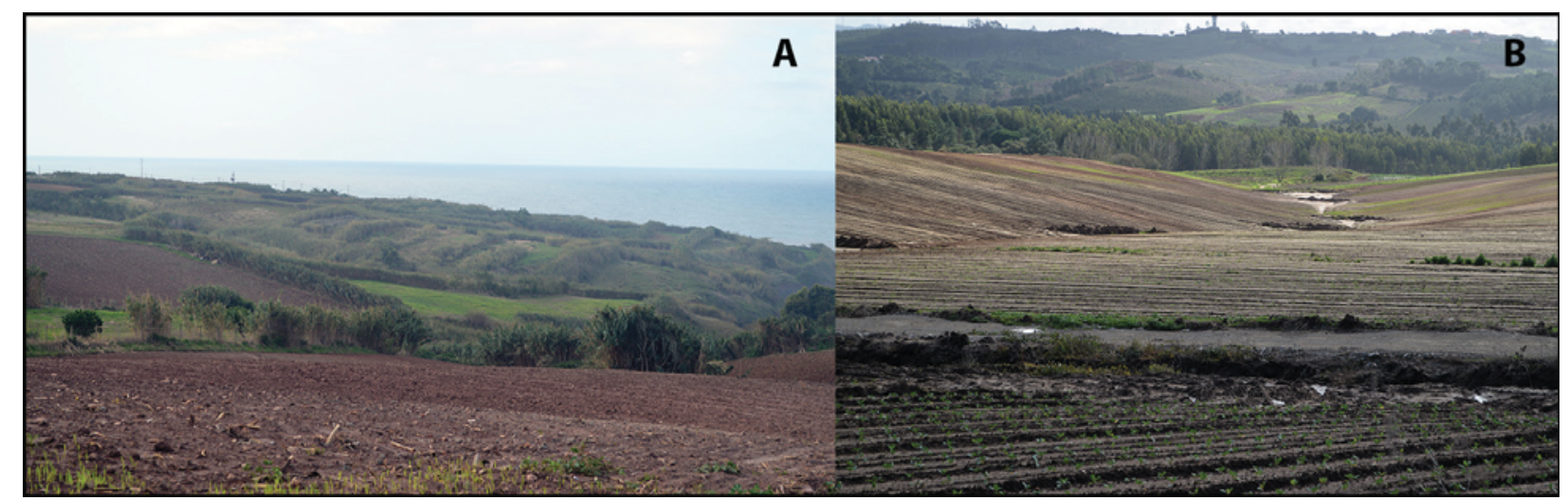

Fig. 10 - Coastal areas with hedgerows (A) and innermost areas with large crop fields (B). Colour figure available online.

Fig. 10 - Áreas costeiras com sebes de compartimentação (A) e áreas de cultivo interiores com grande dimensão (B). Figura a cores disponível online. 
Physical limitations related to rockiness are mostly associated with the limestone formations (land units 8 and 9) in the Cesareda plateau (Ribeiro, 1940; fig. 7), and may have a strong impact on trafficability. Likewise, limitations regarding flooding and drainage must be considered, especially in those areas that apparently did not present constraints for agricultural purposes (as the soil capability map states). Despite drought associated with uneven rainfall distribution, limitations regarding climate may be also strongly associated with the effect of wind in exposed areas, as is suggested by the landscape compartment in areas close to the coast (fig. 10), which in turn may contribute to minimize soil erosion.

\section{CONCLUSIONS}

From the present study, it becomes evident that land unit mapping can potentially provide greater information than the soil capability map. The land unit mapping is an essential tool to assist in landscape planning, by assisting data collection and by improving the information available in soil and soil capability maps, as it may aid in the reorganization, requalification and homogenization of available information. Even in areas with great complexity, as the area under study, land unit mapping enables the outlining of unified methodologies, with identical criteria, to assess the capability and suitability of the land. The land unit mapping may enable the development of a unified system to more accurately delineate management tools (such as the RAN) for the whole country, meeting the general requirements of the existing legislation. Thereby it is an essential support for the landscape planning decisions. As land unit mapping is a top-down process that requires a careful data analysis, further research should be developed in larger areas to clarify its potential benefits regarding land planning in Portugal. The land unit delimitation is an essential tool to improve land limitations assessment and support land capability and suitability classifications.

\section{ACKNOWLEDGEMENTS}

Authors gratefully acknowledge Isabel Roussado for helping handling data and Paulo Marques for fieldwork assistance. The support of Prof. Ana Carla Madeira for English style improvement is also acknowledged.

\section{REFERENCES}

Abreu, A. C., Pinto, T. C., \& Oliveira, R. (2004). Contributos para a Identificação e Caracterização da Paisagem em Portugal Continental [Contribution for the Identification and Cha- racterization of Landscape in Continental Portugal]. Lisboa: Direcção-Geral de Ordenamento do Território e Desenvolvimento Urbano. 
Agroconsultores, Coba. (1991). Carta de Solos, Carta do Uso Actual da Terra e Carta de Aptidão da Terra do Nordeste de Portugal, Escala 1:100 000 [Soil Map, Current Land Use Map and Land Suitability Map of the Northeast of Portugal, Scale 1:100 000]. Vila Real: Universidade de Trás-os-Montes e Alto Douro.

Agroconsultores, Geometral. (1995). Carta dos Solos e Carta de Aptidão para a Agricultura em Entre-Douro e Minho, Escala 1:100 000, Memórias [Soil Map and Suitability Map for Agriculture in Entre-Douro and Minho, Scale 1:100 000, Reports]. Direcção Regional da Agricultura e Entre-Douro e Minho.

Agroconsultores, Geometral. (2004). Elaboração da Carta dos Solos e de Aptidão das Terras da Zona Interior Centro - Memória [Drafting of the Soil Map and Land Suitability Map of the Interior Central Area of Portugal - Report]. Lisboa: Ministério da Agricultura, Pescas e Florestas. Instituto de Desenvolvimento Rural e Hidráulica.

Blasi, C., Zavattero, L., Marignani, M., Smiraglia, D., Copiz, R., Rosati, L., \& Del Vico, E. (2008). The concept of land ecological network and its design using land unit approach. Plant Biosystems, 142(3), 540-549.

Capotorti, G., Guida, D., Siervo, V., Smiraglia, D., \& Blasi, C. (2012). Ecological classification of land and conservation of biodiversity at the national level: the case of Italy. Biological Conservation, $147,174-183$.

Cipriano, R. M. (2001). Vamos Falar da Lourinhã [Lets Talk About Lourinhã]. Lourinhã: Câmara Municipal da Lourinhã.

Decreto-Lei n73/2009 de 31 de Março, Diário da República no 63-31 - I série [Law Decree nº73/2009 of March 31, Official Gazette of the Republic of Portugal no 63-31 - I series]. Ministério da Agricultura do Desenvolvimento Rural e das Pescas.

Direcção-Geral de Agricultura e Desenvolvimento Rural [General Directorate for Agriculture and Rural Development]. Retrieved from: http:// www.dgadr.mamaot.pt/cartografia/cartas-solos cap-uso-analogico

Direcção-Geral do Território (2007). Carta de Ocupação e Uso do Solo (COS 2007) [Soil Cover Map (COS 2007)]. Retrieved from: http://www.dgterritorio. pt/cartografia e geodesia/cartografia/cartografia tematica/cos/cos 2007/
França, J. C, Zbyszewski, G., \& Almeida, F. M. (1960a). Carta Geológica de Portugal na Escala 1:50 000: Folha 26-C Peniche [Geological Map of Portugal in the Scale of 1:50 000: Sheet 26-C Peniche]. Lisboa: Serviços Geológicos de Portugal.

França, J. C., Zbyszewski, G., \& Almeida, F. M. (1960b). Carta Geológica de Portugal na Escala 1:50 000: Notícia Explicativa da Folha 26-C Peniche [Geological Map of Portugal in the Scale of 1:50 000: Explanatory Report of the Sheet 26-C Peniche]. Lisboa: Serviços Geológicos de Portugal.

Grose, C. J. (Eds.) (1999). Land Capability Handbook: Guidelines for the Classification of Agricultural Land in Tasmania. $2^{\text {nd }}$ Edition. Tasmania: Department of Primary Industries, Water and Environment, Launceston.

Food and Agriculture Organization of the United Nations (FAO). (2007). Land evaluation: towards a revised framework. Land and Water Discussion Paper, 6, Rome: FAO.

Food and Agriculture Organization of the United Nations (FAO). (1976). A Framework for land evaluation. Soils Bulletin, 32.

Gomes, A. M. A. (1978). Os Solos de Duas Parcelas de Estudo no Eucaliptal da Quinta de Santo António - Cercal. Suas Características Morfológicas e Esboço Cartográfico [Soils of Two Study Plots in Eucalypt Plantations of Quinta de Santo António - Cercal. Morphological Characteristics and Mapping Draft]. Relatório final da Licenciatura em Engenharia Florestal. Lisboa: Instituto Superior de Agronomia.

Hammond, E. H. (1964a). Analysis of properties in land geography: an application to broad-scale landform mapping. Annals of the Association of the American Geographers, 54(1), 11-19.

Hammond, E. H. (1964b). Classes of land surface form in the forty-eight states, U.S.A. Annals of the Association of the American Geographers, 54(1) (map sup). Retrieved from: https://catalogue.nla. gov.au/Record/6855708

Hammond, E. H. (1954). Small-scale continental landform maps. Annals of the Association of the American Geographers, 44(1), 33-42.

Instituto do Desenvolvimento Rural e Hidráulica (IDRHa). Sociedade Portuguesa da Ciência do Solo (SPCS) (2005). Bases para a Revisão e Actualização da Classificação dos Solos em Portugal [Base for the Review and Update of the Soil 
Classification in Portugal]. Lisboa: Sociedade Portuguesa da Ciência do Solo.

Instituto de Hidráulica, Engenharia Rural e Ambiente (IHERA). (1999). Nota Explicativa da Carta de Solos de Portugal e da Carta de Capacidade de Uso do Solo [Explanatory Report of the Soil Map of Portugal and Soil Capability Map]. Lisboa: Divisão de Solos, Direcção de Serviços dos Recursos Naturais e Aproveitamentos Hidroagrícolas.

IUSS Working Group WRB (2006). World reference base for soil resources 2006. World Soil Resources Reports, 103. Rome: FAO.

Klingebiel, A. A., \& Montgomery, P. H. (1961). Land Capability Classification. Washington: Soils Conservation Service U. S. Department of Agriculture.

Madeira, M. (1986). Influência dos Povoamentos de Eucalipto (E. globulus Labill.) no Solo, Comparativamente aos Povoamentos de Sobreiro (Q. suber L.) e de Pinheiro (P. pinaster Ait.) [Influence of Eucalytus Plantations (E. globulus Labill.) on Soil, Relative to Cork Oak (Q. suber L.) and Pine (P. pinaster Ait.) stands]. Tese de doutoramento. Lisboa: Instituto Superior de Agronomia..

Manuppella, G., Antunes, M. T., Pais, J., Ramalho, M. M., \& Rey, J. (1999a). Carta Geológica de Portugal na Escala 1:50 000: Folha 30-A Lourinhã [Geological Map of Portugal in the Scale of 1:50 000: Sheet 30-A Lourinhã]. Lisboa: Instituto Geológico e Mineiro.

Manuppella, G., Antunes, M. T., Pais, J., Ramalho, M. M., \& Rey, J. (1999b). Carta Geológica de Portugal na Escala 1:50 000: Notícia Explicativa da Folha 30-A Lourinhã [Geological Map of Portugal in the Scale of 1:50 000: Explanatory Report of the Sheet 30-A Lourinhã]. Lisboa: Instituto Geológico e Mineiro.

Marques, P. J. P. (2010). Os Solos da Mata Nacional de Leiria: Características e Classificação [The Soils of the Leiria National Forest: Characteristics and Classification]. Dissertação de Mestrado em Engenharia Agronómica. Lisboa: Instituto Superior de Agronomia.

Mendes, A. R. (2010). Avaliação da Qualidade Cénica da Paisagem: Aplicação da Metodologia de Steinitz ao Litoral Alentejano [Landscape Scenic Quality Evaluation: Aplication of Steinitz Methodology to the Alentejo Coast]. Dissertação de Mestrado em Arquitectura Paisagista. Lisboa: Instituto Superior de Agronomia.
Morgan, J. M., \& Lesh, A. M. (2005). Developing Landform Maps Using ESRI's Modelbuilder. Baltimore: Towson University Center for Geographic Information Sciences.

Office of Environment and Heritage (OEH). (2012). The Land and Soil Capability Assessment Scheme. Second Aproximation. Sydney: New South Wales Government.

Reis, R. M., \& Gonçalves, M. (1981). O Clima de Portugal: Caracterização Climática da Região Agrícola do Ribatejo e Oeste [The Climate of Portugal: Climatic Characterization of the Oeste and Ribatejo Agricultural Region]. Lisboa: Instituto Nacional de Meteorologia e Geofísica.

Ribeiro, A. L. (1940). Monografia da Freguesia de Reguengo Grande (Concelho de Lourinhã) [Monography of Reguengo Grande Parish (Lourinhã Municipality)]. Anais do Instituto Superior de Agronomia, Vol. XI, Lisboa: Universidade Técnica de Lisboa.

Serviço de Reconhecimento e Ordenamento Agrário (SROA). (1973). Carta dos Solos de Portugal. Classificação e Caracterização dos Solos de Portugal: Dados Analíticos das Unidades Pedológicas [Soil Map of Portugal. Classification and Characterization of the Soils of Portugal: Analytical Data of Soil Units]. Vol. II, 6a ed. Lisboa: Secretaria de Estado da Agricultura, Ministério da Economia.

Serviço de Reconhecimento e Ordenamento Agrário (SROA). (1972). Carta de Capacidade de Uso do Solo de Portugal: Bases e normas adoptadas na sua elaboração [Soil Capability Map of Portugal: Basis and Standards adopted for its Elaboration]. Boletim de Solos do SROA, 12, 1-195.

Sousa, E. C., Madeira, M., \& Monteiro, F. G. (2004). A Base de Referência para os Solos do Mundo e a Classificação dos Solos de Portugal [World Reference Base for Soil Classification and the Classification of the Soils of Portugal]. Revista de Ciências Agrárias, 27(1),13-23.

Zbyszewski, G. (1966a). Carta Geológica de Portugal na Escala 1:50 000: folha 30-B Bombarral [Geological Map of Portugal in the Scale 1:50 000: Sheet 30-B Bombarral]. Lisboa: Serviços Geológicos de Portugal.

Zbyszewski, G. (1966b). Carta Geológica de Portugal na Escala 1:50 000: Notícia Explicativa da Folha 30-B Bombarral [Geological Map of Portugal in 
the Scale 1:50 000: Explanatory Report of the Sheet 30-B Bombarral]. Lisboa: Serviços Geológicos de Portugal.

Zbyszewski, G., \& Almeida, F. M. (1960a). Carta Geológica de Portugal na Escala 1:50 000: Folha 26-D Caldas da Rainha [Geological Map of Portugal in the Scale 1:50 000: Sheet 26-D Caldas da Rainha]. Lisboa: Serviços Geológicos de Portugal.

Zbyszewski. G., \& Almeida, F. M. (1960b). Carta Geológica de Portugal na Escala 1:50 000: Notícia Explicativa da Folha 26-D Caldas da Rainha
[Geological Map of Portugal in the Scale 1:50 000: Explanatory Report of the Sheet 26-D Caldas da Rainha]. Lisboa: Serviços Geológicos de Portugal.

Zonneveld, I. S. (1995). Land Ecology: An Introduction to Landscape Ecology as a Base for Land Evaluation, Land Management and Conservation. Amsterdam: SPB Academic Publishing.

Zonneveld, I. S. (1989). The land unit: a fundamental concept in landscape ecology and its applications. Landscape Ecology, 3(2), 67-86.

i The terms "soil capability map" and "soil capability classification" are a translation of the Portuguese terms carta de capacidade de uso do solo and classificação da capacidade de uso do solo, which approximately correspond to the land capability classification (Klingebiel \& Montgomery, 1961). Although the aim was to develop a classification based on the land capability classification (by the United States Soil Conservation Service), the soil capability classification (in Portugal) did not consider the climate and was based on less detailed soil information as compared to that used in the USA (SROA, 1972).

ii Unidades de Terra is the concept defined in the Legal Regime of the National Agricultural Reserve: portions of the territory possessing a high degree of homogeneity with respect to their physical characteristics, especially in the agro-climatic, morphological and pedological aspects. 